\title{
Evaluation of School-Based Tuberculosis Screening Results After Index Case (Both Intellectual Disability and Cavitary Pulmonary Tuberculosis)
}

\section{Zihinsel Engellilik ve Kaviter Akciğer Tüberküloza Sahip İndex Vaka Sonrası Okul Temelli Tüberküloz Tarama Sonuçlarının Değerlendirilmesi}

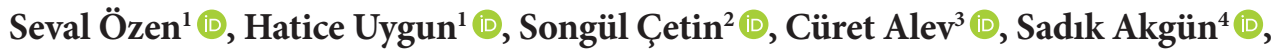 \\ İbrahim Hakan Bucak ${ }^{5}$ (D), Mehmet Turgut ${ }^{1}$ (D)
}

\footnotetext{
1 Adryaman University Faculty of Medicine, Department of Pediatric, Division Pediatric Infection Disease, Adıyaman, Turkey

2 Adıyaman Tuberculosis Center, Adıyaman, Turkey

3 Adıyaman Education and Research Hospital, Medical Microbiology, Adıyaman, Turkey

${ }^{4}$ Adıyaman Faculty of Medicine, Medical Microbiology, Adıyaman, Turkey

${ }_{5}$ Adiyaman University Faculty of Medicine, Department of Pediatric, Adiyaman, Turkey
}

ORCID: S.Ö. 0000-0001-8342-3786;

H.U. 0000-0002-8695-9129;

S.Y. 0000-0001-7451-1653;

C.A. 0000-0002-9491-0325;

S.A. 0000-0002-1413-0450;

İ.H.B. 0000-0002-3074-6327;

M.T. $0000-0002-2155-8113$

Corresponding author/Sorumlu yazar: Seval Özen,

Adıyaman University Medical Faculty Pediatric Infectious Diseases Department, Adıyaman, Turkey

E-mail: drsevalcevik@hotmail.com

\section{Submitted/Gelis tarihi: 17.05.2021} First Revision Received/İlk revizyon: 06.08.2021 Last Revision Received/Son Revizyon: 16.08.2021 Accepted/Kabul Tarihi: 26.08 .2021

Citation /Atıf: Ozen S, Uygun H, Yildiz S, Alev C, Akgun A, Bucak IH, et al. Evaluation of schoolbased tuberculosis screening results after index case (both intellectual disability and cavitary pulmonary tuberculosis). Sağlık Bilimlerinde İleri Araștırmalar Dergisi 2021; 4(3): 105-112. https://doi.org/10.26650/JARHS2021-938552

\begin{abstract}
Objective: Tuberculosis is an important public health problem. Tuberculosis prevalence is high in low-income countries. It is contagious, and therefore a risk for people in public living areas. It is contagious, and therefore a risk for people in public areas. Also, people with intellectual disability stay in the same public areas. Therefore, they are also at risk. The aim of our study was to investigate the contact of persons in the same center with an index case.

Materials and methods: Contact investigation was conducted in a training and rehabilitation center. Tuberculosis-specific parameters were measured from the patients.

Results: All contacts $(n=39)$ were male. Fifteen contacts were offered follow-up without medication. Fifteen contacts were given medication for prophylaxis. Latent tuberculosis was detected in 8 patients. Possible tuberculosis was detected in one patient. Contagion of tuberculosis from the index case to his roommates measured $16.6 \%$. Tuberculosis contagion from the patient with possible tuberculosis to his roommates measured $37.5 \%$. Patients with latent tuberculosis and possible tuberculosis were medicated according to international criteria. Conclusion: People with intellectual disability do not fully define the symptoms of the disease. Therefore, the prognosis may be made when the disease is diagnosed by a health professional. Also, some tests may not be performed because communication is not possible. For this reason, clinicians should be more careful in screening people with intellectual disability for TB. Also, the fight against tuberculosis should be continued without interruption.

Keywords: Contact screening, intellectual disability, school-based tuberculosis, cavitary pulmonary tuberculosis
\end{abstract}

ÖZ

Amaç: Tüberküloz önemli bir halk sağlığı sorunudur. Düșük gelirli ülkelerde tüberküloz prevalansı yüksektir. Bulaşıcıdır, bu nedenle toplu yaşam alanlarındaki insanlar için bir risktir. Ayrıca zihinsel engelli insanlar aynı toplu yaşam alanlarında kalırlar. Bu nedenle, onlar da risk altındadır. Çalışmamızın amacı aynı merkezde kalan indeks vaka ile temaslı çocukların tarama sonuçlarının paylaşılması ve temaslarını incelemektir.

Gereç ve Yöntem: Temas araştırması bir Zihinsel Engelliler Rehabilitasyon ve Eğitim Merkezinde yapılmıștır. Hastalarda tüberküloza özgü parametreler değerlendirildi.

Bulgular: Otuz dokuz hastanın tamamı erkekti (\%100). On beş kişi ilaçsız takip edildi. On beş kişiye profilaksi verildi. Sekiz hastada latent tüberküloz tespit edildi. Bir hastada olası tüberküloz tespit edildi. İndeks vakadan oda arkadaşlarına tüberküloz iletimi \%16.6 iken olası tüberküloz hastasından oda arkadaşlarına tüberküloz iletimi \%37.5 olarak saptandı. Latent tüberküloz ve olası tüberküloz tanısı alan hastalar, uluslararası kriterlere göre tedavi edilmiştir. Sonuç: Zihinsel engelli kişiler, hastalı̆̆ın semptomlarını tam olarak tanımlayamazlar. Bu nedenle, hastalık bir sağlık profesyoneli tarafından teşhis edildiğinde hastalık ilerleyebilir. Ayrıca, iletişim mümkün olmadığından bazı testler gerçekleştirilemeyebilir. Bu nedenle, klinisyenler zihinsel engeli olan kişilerin taramasında daha dikkatli olmalıdır. Ayrıca tüberküloz ile mücadeleye ara vermeden devam edilmelidir.

Anahtar Kelimeler: Temas taraması, zihinsel engellilik, okul temelli tüberküloz, kaviter akciğer tüberkülozu 


\section{INTRODUCTION}

Tuberculosis (TB) is an important public health problem because of its high mortality and morbidity rate (1). The prevalence of TB is high in low-income countries $(2,3)$. TB is contagious and a risk for people in public areas public living areas (schools, etc.) (4). People with intellectual disability (ID) stay also in the same public areas. public living areas. Therefore, they are also at risk. ID can be caused by an infection, trauma, etc. in intrauterine life. Research has shown that ID has wide prevalence values (5). ID is classified as very mild, mild, moderate or severe. The prevalence of mild classification was higher than others $(6,7)$.

When healthy people become ill, they can define their symptoms through communication methods. However, this communication is not generally possible in people with ID. For this reason, it is often too late when a contagious disease is detected in the ID. In our study, a 13-year-old child with ID was admitted to our hospital because of cough, fever, weight loss and bloody sputum. As a result of the analysis, the patient was diagnosed with cavitary pulmonary tuberculosis (index case). The patient was staying in an education-rehabilitation center. Therefore, we thought the disease might be contamination from an index case to other individuals in the center. For this reason, the first school-based contact screening of tuberculosis was performed in our region.

\section{MATERIAL AND METHODS}

\section{Index Case}

A 13-year-old male patient was admitted to our hospital with a cough (lasting 2 months), high fever, weight loss and bloody sputum (lasting a week). A posterior-anterior (PA) chest X-ray detected a suspicious cavitary lesion in the right lung. This cavitary lesion was localized at the right hilar region. Also, consolidation was detected in the right middle lung. He was hospitalized with a preliminary diagnosis of tuberculosis infection. The patient had been residing in the rehabilitation center for 6 months. At the same time, the patient had ID (moderate), autism and epilepsy. We learned that the patient was taking sodium valproate, valproic acid and mirtazapine.

Physical Examination: Weight percentile was measured <3p (weight: $31 \mathrm{~kg}$ and height: $148 \mathrm{~cm}$ ). On examination, he was tired, sleepless and depressed. He had cachexia and crepitant rales in both lungs. There was one BCG scar in the left deltoid muscle.

Laboratory Results: Parameters were measured as leukocyte lökosit: 13.150/ul, albumin: $2.4 \mathrm{gr} / \mathrm{dl}$, C-reactive protein: $0.2 \mathrm{mg} / \mathrm{dl}$. Test results showed immune fluorescent antibody pneumonia negative, galactomannan negative, gastric lavage and bronchoalveolar lavage acid-fast bacilli stain (AFBS) negative and tuberculin skin test (TST): $0 \mathrm{~mm}$, QuantiFERON-TB Gold In-tube test (QFT) positive. The mycobacterium tuberculosis complex polymerase chain reaction was positive.

Radiological Results: In the right lung; pretracheal and pericarinal lymphadenopathy (max diameter: $2 \mathrm{~cm}$ ), stenosis of lower lobe bronchus, peribronchovascular sheath thickening areas in the right-upper and middle lobe, cavitary areas above lower lobe and consolidation with air bronchograms were detected in PA chest X-ray and thorax computed tomography (CT) (Figure 1,2). Bronchoscopy was performed because of stenosis of lower lobe of the right lung. There was no pathology in the bronchoscopy (mass, foreign body, etc.).

Diagnosis: The patient was diagnosed with cavitary pulmonary TB due to the presence of mass living

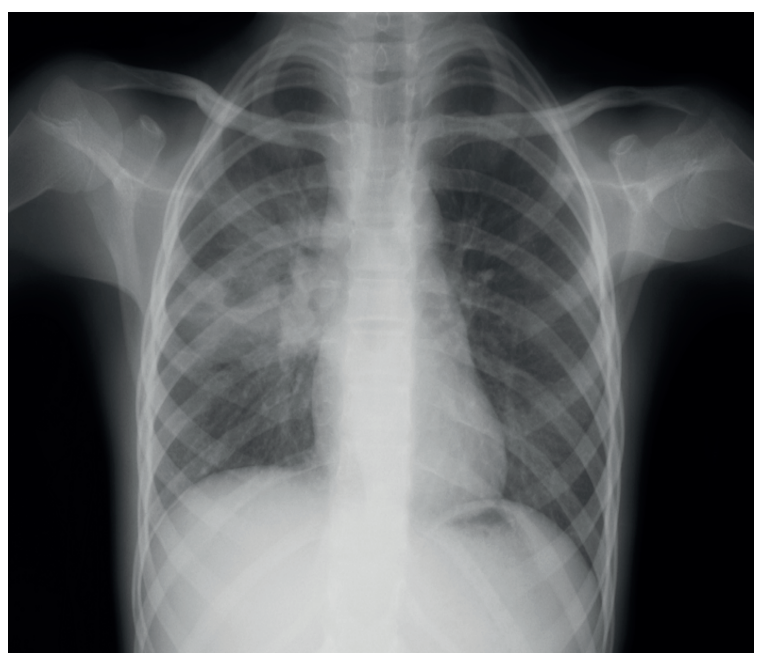

Figure 1. Index case chest X-ray 


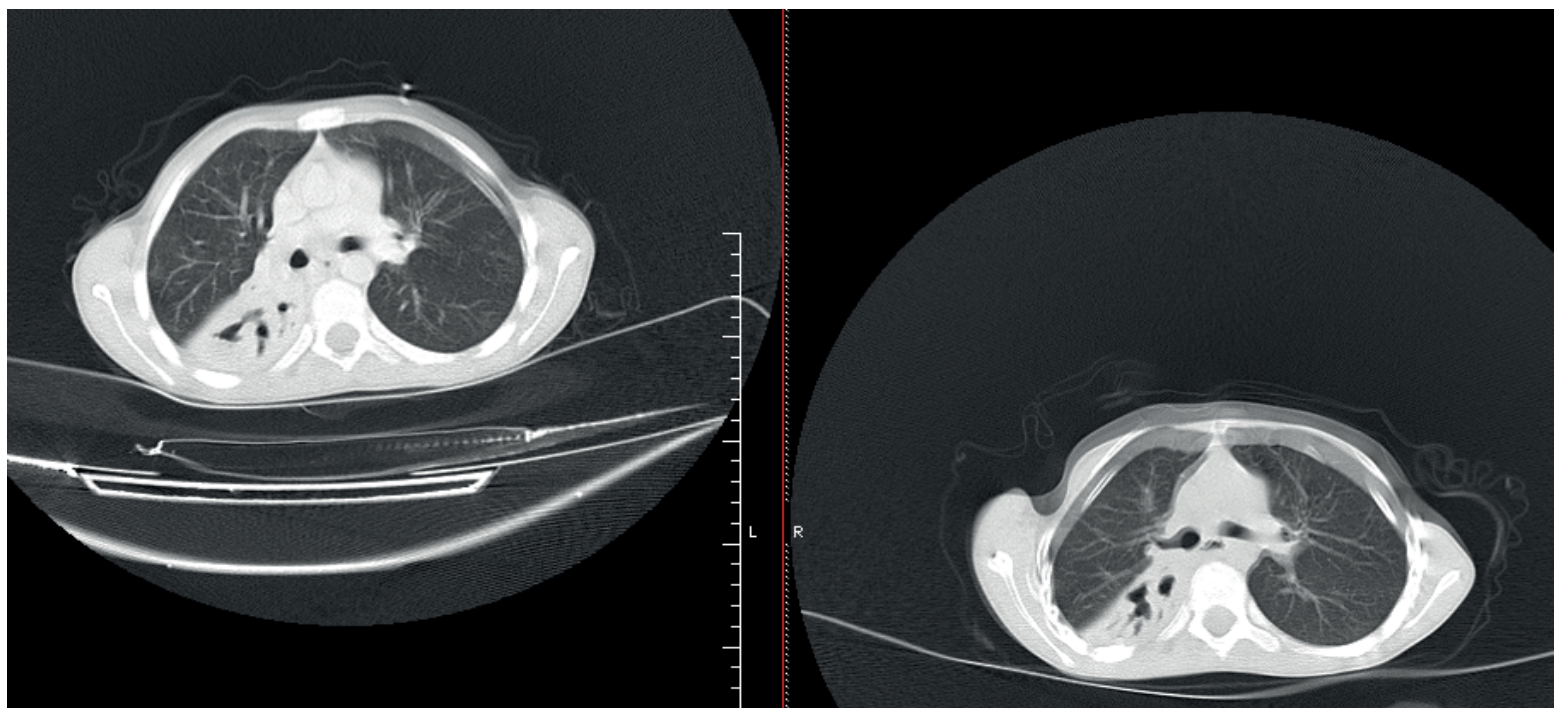

Figure 2. Index case thorax CT

area, weight loss, cough, history of bloody sputum, cavitary lesion on radiological results, lymphadenopathy, consolidation areas and QFT (positivity). Diagnosis was based on internationally recognized criteria $(8,9)$.

Treatment and Isolation: Drug treatment was started (4 drugs for 2 months: Isoniazid ( $15 \mathrm{mg} / \mathrm{kg} /$ day, max: $300 \mathrm{mg}$, a single dose, per oral), Rifampicin (15 mg/kg/day, max: $600 \mathrm{mg}$, a single dose, per oral), Pyrazinamide (30 mg/kg/day, a single dose, per oral), Streptomycin $(20 \mathrm{mg} / \mathrm{kg} /$ day, a single dose, intramuscular). Maintenance therapy was started at the end of this period ( 2 drugs for 4 months: Isoniazid: 15 $\mathrm{mg} / \mathrm{kg} /$ day, Rifampicin: $15 \mathrm{mg} / \mathrm{kg}$ /day and pyridoxine). Treatment was based on internationally recognized criteria $(8,9)$. The patient was treated in an isolation room for 3 weeks. A thorax CT was performed 6 months later. This CT showed a marked reduction in the cavitary lesion and surrounding consolidation areas in the thorax (Figure 3).

\section{Contact Assessment}

We learned that the index case was staying at the same center with thirty-nine children. Also, all the children had ID at different levels. For this reason, contact research was conducted. Age, height, weight, BCG scar count, medical anamnesis and proximity to index cases were measured in children. At the same time, ID levels were learned. A physical examination

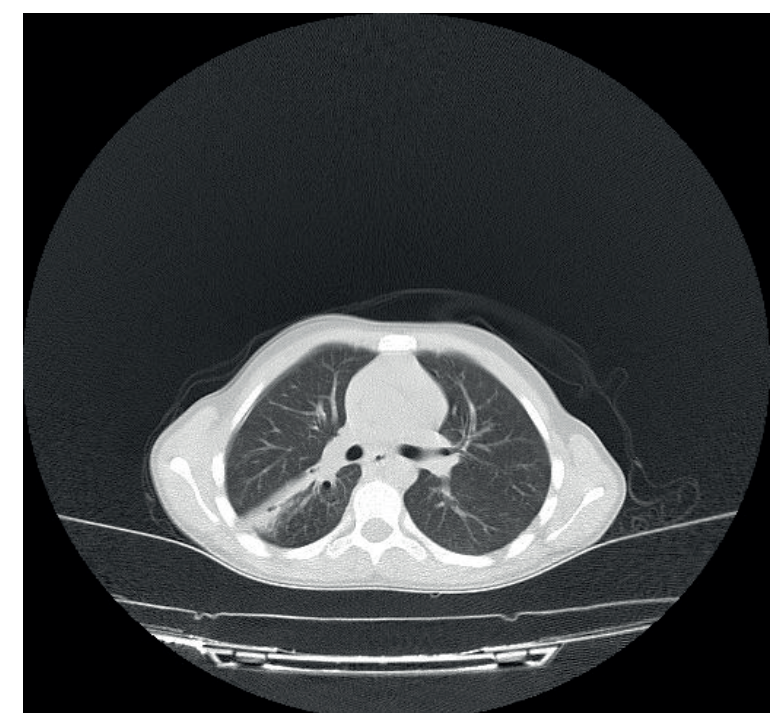

Figure 3. Six months later thorax CT

was performed on all children, along with PA chest $\mathrm{X}$-rays and TSTs (6). Two weeks later, QFT were performed (10) and thorax CT were performed if necessary. Four AFBS were collected. National and international criteria for TB diagnosis were utilized $(8,9)$. This study was conducted in an education and rehabilitation center in Adiyaman province.

\section{Data Analysis and Ethics Committee}

Descriptive statistics were used for the data. Data is given as n, \%, mean, and standard deviation. Ethics committee approval was received by Adryaman University Non-Interventional Clinical Research Ethics Committee (2019/2-37). 

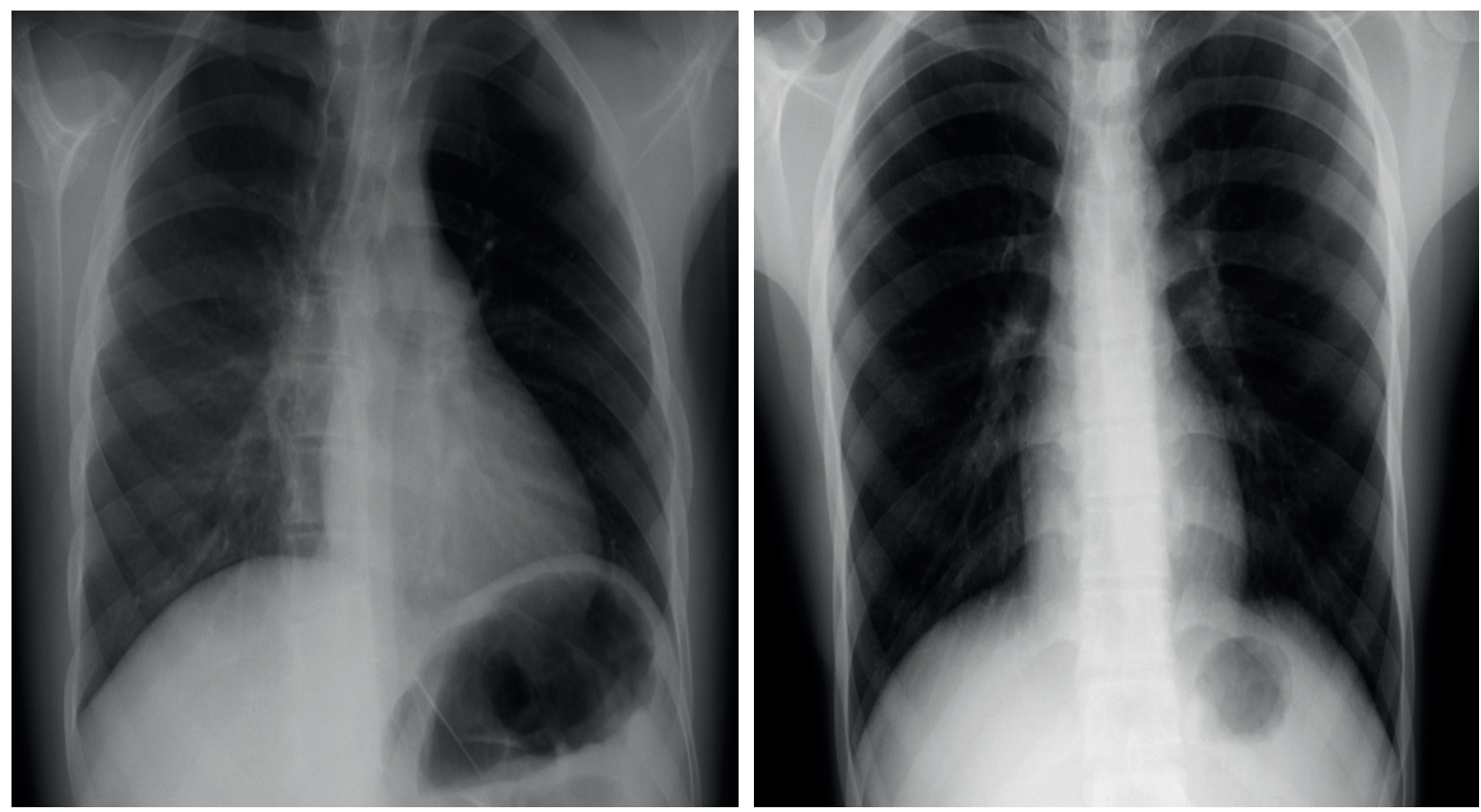

Figure 4. Radiological result of a few patients diagnosed with Latent TB

\section{RESULTS}

All contacts $(n=39)$ were male. Age: $14.9 \pm 1.78$ years, weight: $54.69 \pm 14.33 \mathrm{~kg}$, height: $162.53 \pm 13.22$ $\mathrm{cm}$ and $12.8 \%$ of the weight percentile was measured $<3$ p. Only one of the patients with a positive TST had no BCG scar. The diameter of TST positive patients was $14.80 \pm 4.76 \mathrm{~mm}$. Positive TST was recorded in 4 (10.26\%) patients who were tested, and the induration size: $14.80 \pm 4.76 \mathrm{~mm}$. Only four AFBS samples were collected because communication could not be established. All four samples were negative (Table I.)

\section{Normal Result and Prophylaxis}

Fifteen patients [TST (negativity), QFT (negativity) and in the same center but in different rooms] were offered follow up without medication. Fifteen patients (close contact and in same room with index case) started drug treatment for prophylaxis (Isoniazid: $10 \mathrm{mg} / \mathrm{kg} /$ day, max: $300 \mathrm{mg}$, a single dose, 6 months, per oral).

Latent TB: Eight patients [TST (positivity) or QFT (positivity) and close contact with index case] were diagnosed with latent TB. Drug treatment was started in these patients (Isoniazid: $10 \mathrm{mg} / \mathrm{kg} /$ day, max: $300 \mathrm{mg}$, a single dose, 6 months).

Possible TB: One patient [TST (positivity), QFT (positivity) and close contact with index case] was diagnosed with possible TB. This patient had TST: 19 mm, QFT (positivity), BCG scar (positivity), TB-specific symptom (positivity) and pathology in thorax CT and PA chest X-ray (Figure 4). An api-

Table 1. The characteristics of the patients

\begin{tabular}{|c|c|c|c|}
\hline & Factor & $\mathbf{n}$ & $\%$ \\
\hline \multirow{4}{*}{ ID } & Very Mild & 5 & 12 \\
\hline & Mild & 13 & 33 \\
\hline & Moderate & 13 & 33 \\
\hline & Severe & 9 & 23 \\
\hline \multirow{3}{*}{$\begin{array}{l}\text { BCG Scar } \\
\text { Count }\end{array}$} & 0 & 11 & 28.2 \\
\hline & 1 & 27 & 69.2 \\
\hline & 2 & 1 & 2.6 \\
\hline \multirow{2}{*}{ TST } & Positive & 4 & 10.26 \\
\hline & Negative & 35 & 89.74 \\
\hline \multirow{2}{*}{ QFT } & Positive & 5 & 12.82 \\
\hline & Negative & 34 & 87.18 \\
\hline \multirow{2}{*}{$\begin{array}{l}\text { PA Chest } \\
\text { X-ray }\end{array}$} & Pathologic ${ }^{*}$ & 10 & 25.64 \\
\hline & $\begin{array}{c}\text { Non-Patho- } \\
\text { logic }\end{array}$ & 29 & 74.36 \\
\hline \multirow[b]{2}{*}{ Toraks CT ${ }^{* *}$} & Pathologic & 3 & 30 \\
\hline & $\begin{array}{l}\text { Non-Patho- } \\
\text { logic }\end{array}$ & 7 & 70 \\
\hline
\end{tabular}

* Lobe-segmental consolidation, cavitation, atelectasis, hilar lymph adenomegaly, etc. were considered in favor of TB. ${ }^{* *}$ Chest $\mathrm{X}$-ray was taken with pathological results. 

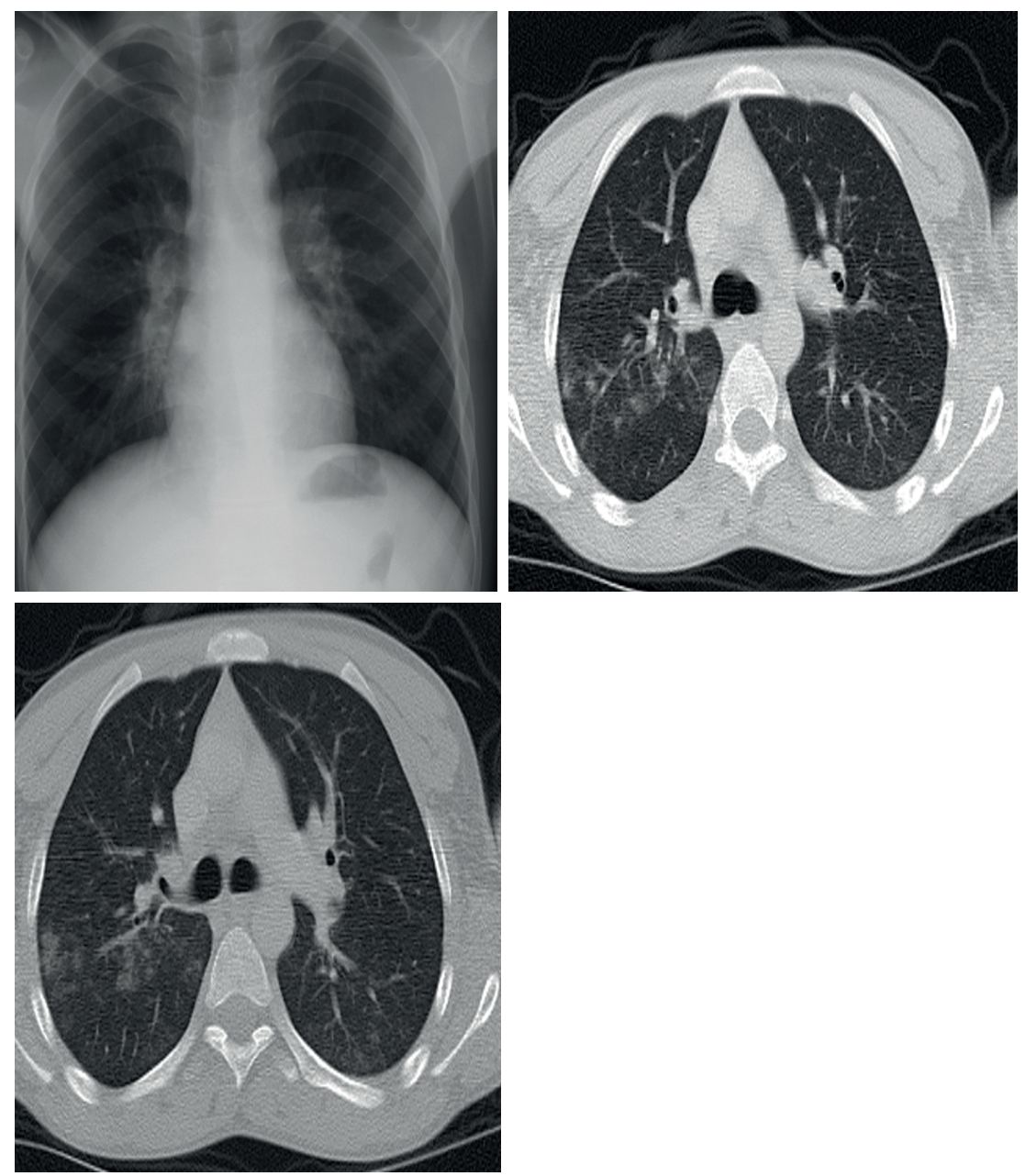

Figure 5. Radiological results of Possible TB

co-posterior consolidation area and low-lobe superior segment consolidation area were detected in the thorax CT. This patient was started on the following treatment for 2 months: Isoniazid $(15 \mathrm{mg} / \mathrm{kg} / \mathrm{day}$, max: $300 \mathrm{mg}$, a single dose, per oral), Rifampicin (15 $\mathrm{mg} / \mathrm{kg} /$ day, max: $600 \mathrm{mg}$, a single dose, per oral) and Pyrazinamide (30 mg/kg/day, a single dose, per oral). After 2 months of treatment, 4 months of Isoniazid and Rifampicin was started.

Contagion of TB infection to the roommates of the index case measured $16.6 \%$. TB contagion to roommates of a possible TB patient measured 37.5\%.

\section{DISCUSSION}

Tuberculosis (TB) is an important public health problem worldwide due to its high mortality and morbidity. The prevalence of TB is high in low-inco- me countries (1-3). According to the WHO, it is estimated that there are approximately 10 million TB cases and 3 million TB-related deaths each year in the world (11). The prevalence of childhood TB infection varies between 7 and 23\% (12). TB rates in the 15-24 age range (16\%) are known to be high in Turkey (13). ID can be caused by a negative condition (infection, trauma, etc.) in intrauterine life. Research has shown that the prevalence of ID varies (5-7). When healthy people become ill, they define their symptoms through communication. However, this communication may not be possible in individuals with ID. For this reason, it is often too late when a disease occurs in someone with ID. The aim of this study was to investigate the disease status of individuals in contact with an index case.

Pulmonary cavitation can develop with tissue 
destruction at 1-3 years after primary TB infection in adolescence. Radiological appearance in adolescents is similar to adults (14). Some conditions may increase the risk of TB transmission (bacillus positivity, contact time, proximity of contact, age, etc.) $(9,15)$. In our study, in addition to index cases, there are some special situations (ID, away from family, communication difficulties, etc.). Therefore, we believe that TB creates a cavity due to a number of factors. We think that TB is diagnosed late due to a number of factors. Generally, patients may receive infection from close contact with an infectious adult or adolescent living in the same household.

$30-50 \%$ of people who share the same house with a patient with TB have a reactive TDT. In our study, the rate of TB infection from index case to roommates measured $16.6 \%$. Rate of TB transmission from a patient with possible TB to roommates measured $37.5 \%$. School-based studies have shown that this transition is between $66.7 \%$ and $72.4 \%$ (16-18). In our study, we think that low TB transition compared to other studies may be related to the special situation of the index case (ID, cachectic, poor cough reflex, etc.). In our study, 8 people (20\%) were diagnosed with latent TB. In one study $(\mathrm{n}=206)$, it was reported that latent TB was detected in 37 children (17.96\%) (19). In another study $(\mathrm{n}=327)$, TB prevalence was shown to be high in kindergarten-age children (20). In a contact study (Index Case=7), it was reported that households had higher TB parameters than schools (21). In our study, the main reason for our detection of possible TB and latent TB can be explained with long-term but minimal contact with the index case.

In a study $(\mathrm{n}=8)$ conducted in a region where TB prevalence is high, AFBS (positive) was found in $87.5 \%$ of patients (age $=10-14$ ) diagnosed with cavitary lung tuberculosis (20). In order for AFBS parameter to be analyzed well, the sputum must be taken in sufficient quantities, at the right time and correctly (22). In our study, all of the samples were negative for AFBS. We believe that the main reason for this situation is not getting adequate and high-quality samples from people with ID.

\section{CONCLUSION}

People with ID do not fully define the symptoms of their disease. Therefore, prognosis may be made when the disease is diagnosed by the health professional. Also, some tests may not be taken because communication is not possible. For this reason, clinicians should be more careful in screening for TB in people with IDs. Also, the fight against TB should be continued without interruption.

Hakem Değerlendirmesi: Dış bağımsız.

Peer Review: Externally peer-reviewed.

Bilgilendirilmiş Onam: Katılımcılardan bilgilendirilmiş onam alınmıştır.

Informed Consent: Written consent was obtained from the participants.

Etik Komite Onayı: Bu çalışma için etik komite onayı Adıyaman Üniversitesi Girişimsel Olmayan Araştırmalar Etik Kurulu’ndan alınmıştır (No: 2019/237, Tarih: 20.03.2019).

Ethics Committee Approval: This study was approved by the Adiyaman University NonInterventional Clinical Research Ethics Committee (No: 2019/2-37, Tarih: 20.03.2019).

Yazar Katkıları: Çalışma Konsepti/Tasarım- S.Ö., M.T.; Veri Toplama-H.U., S.Ö., S.Y., C.A.,S.A.; Veri Analizi/Yorumlama- S.Ö., M.T., H.U.; Yazı Taslağ1S.Ö., M.T.; İçeriğin Eleştirel İncelemesi- M.T., İ.H.B.; Son Onay ve Sorumluluk- S.A., N.K.

Author Contributions: Conception/Design of Study- S.Ö., M.T.; Data Acquisition- H.U., S.Ö., S.Y., C.A.,S.A.; Data Analysis/Interpretation- S.Ö., M.T, H.U.; Drafting Manuscript-M.T., İ.H.B.; Critical Revision of Manuscript- S.Ö., M.T.; Final Approval and Accountability- S.A., N.K.

Çıkar Çatışması: Yazarlar çıkar çatışması beyan etmemişlerdir

Conflict of Interest: Authors declared no conflict of interest.

Finansal Destek: Yazarlar finansal destek beyan etmemişlerdir.

Financial Disclosure: Authors declared no financial support. 


\section{REFERENCES}

1-Raviglione MC, Snider DE, Kochi A. Global epidemiology of tuberculosis: morbidity and mortality of a worldwide epidemic. JAMA 1995;273(3):220-6.

2- Jenkins HE, Tolman AW, Yuen CM, Parr JB, Keshavjee S, Pérez-Vélez CM, et.al. Incidence of multidrug-resistant tuberculosis disease in children: systematic review and global estimates. Lancet 2014;383(9928):1572-9.

3- Centers for Disease Control and Prevention. Estimates for future global tuberculosis and mortality. JAMA 1994; 271:739-40.

4-Singh M, Mynak ML, Kumar L, Mathew JL, Jindal SK. Prevalence and risk factors for transmission of infection among children in household contact with adults having pulmonary tuberculosis. Arch Dis Child 2005;90(6):624-8.

5-Cooper SA, Smiley E, Morrison J, Williamson A, Allan L. Mental ill-health in adults with intellectual disabilities: prevalence and associated factors. Br J Psychiatry 2007;190(1):27-35.

6-Harris JC. Intellectual disability: Understanding its development, causes, classification, evaluation, and treatment. England, Oxford University Press. 2006:42-5.

7-King N, Lancaster N, Wynne G, Nettleton N, Davis R. Cognitive-behavioral anger management training for adults with mild intellectual disability. Scand J Behav Ther 1999;28(1):19-22.

8- Sağlık Bakanlığı, Tüberküloz Tanı ve Tedavi Rehberi, Akdağ R. (eds), Ankara, 2011:71-8.

9- World Health Organization. Recommendations for investigating contacts of persons with infectious tuberculosis in low-and middleincome countries, Genova, 2012 (No. WHO/ $\mathrm{HTM} / \mathrm{TB} / 2012.9$ )

10- Mazure GH, Jereb J, LoBue P, Iademarco MF, Vernon A. Guidelines for Using the QuantiFERON-TB G Test for Detecting Mycobacterium tuberculosis Infection, United States.MMWR 2005;15:49-55.

11- World Health Organization. Global Tuberculosis Report, 20th Edition, Geneva, 2015, ISBN 9789241565059.
12-Chiang SS, Starke JR. Mycobacterium Tuberculosis. In: Long SS, Prober CG, Fischer M (eds). Principles and Practice of Pediatric Infectious Disease. 5th ed. Philadelphia: Elsevier, 2018:4026-81.

13-Kabasakal E, Yıldırım A, Mutlu M, Baykal F. Kara F (eds). Türkiye'de Verem Savaşı 2018 Raporu. Ankara, 2018:11-13.

14-Schepisi MS, Motta I, Dore S, Costa C, Satgiu G, Giordi E. Tuberculosis transmission among children and adolescents in schools and other congregate settings: a systemic review. New Microbiologica 2018;41;(4):282-90.

15- Mandalakas AM, Kirchner HL, Lombard C, Walzl G, Grewal HM, Gie RP, Hesseling AC. Wellquantified tuberculosis exposure is a reliable surrogate measure of tuberculosis infection. Int J Tuberc Lung Dis 2012;16(8):1033-9.

16- Roberts JR, Mason BW, Paranjothy S, Palmer SR. The transmission of tuberculosis in schools involving children 3 to 11 years of age. Pediatr Infect Dis J 2012; 31:82-4.

17- Molicotti P, Bua A, Mela G, Olmeo P, Delogu R, Ortu S, et.al. Performance of QuantiFERON-TB testing in a tuberculosis outbreak at a primary school. J Pediatr 2008;152(4):585-6.

18- Paranjothy S, Eisenhut M, Lilley M, Bracebridge S, Abubakar I, Mulla R, et al. Extensive transmission of Mycobacterium tuberculosis from 9 year old child with pulmonary tuberculosis and negative sputum smear. BMJ 2008:28;337.a1184.

19- Kara S, Büyükvanlı F, Öngel K, Yıldırım Baş F, Türker Y. Akciğer Tüberkülozlu Servis Şöförü İle Temas Sonrasında Bir İlköğretim Okulunda Yapılan Tarama Sonuçları. 2.Trakya Aile Hekimliği Kongresi, Turkey, 2012.

20- Kim D, Lee S, Kang SH, Park MS, Yoo SY, Jeon TY et al. A contact investigation after exposure to a child with disseminated tuberculosis mimicking inflammatory bowel disease. Korean J Pediatr 2018;61(11):366.

21- Ustero PA, Kay AW, Ngo K, Golin R, Tsabedze B, Mzileni B et al. School and household tuberculosis contact investigations in Swaziland: active TB case finding in a high HIV/TB burden setting. PloS one 2017;12(6):e0178873. 
22-Lutpiatina L, Wahidah W, Nurhilaliah N, Rakhmina D, Rifqoh R. Sputum Quality of The Anytime and Outset for Examination AcidResistance Bacilli. MLTJ 2018;4(1):26-9. 